\title{
Highly expression of Tim-3 on HIV-specific T cells associated with disease progression and T-cell exhaustion in HIV-1 infected Chinese
}

\author{
Z Liu, K Hong ${ }^{*}$, M Jia, J Hao, Z Gao, S Liu, Y Ruan, H Xing, Y Shao \\ From AIDS Vaccine 2012 \\ Boston, MA, USA. 9-12 September 2012
}

\section{Background}

The exact mechanism of $\mathrm{T}$-cell exhaustion remains to be defined during HIV-1 infection. Recent studies suggest that the inhibitory receptor $\mathrm{T}$-cell immunoglobulin domain and mucin domain 3(Tim-3) may play an important role in the exhaustion of HIV-specific T cells.

\section{Methods}

72 HIV-1 infected individuals with different disease outcomes were recruited in this study. Tim-3 expression and the profile of cellular immune response were measured by using Multicolor Intracellular Cytokine Staining (ICS) assay. Association between Tim-3 expression levels and disease progression was analyzed. And the potential role of Tim-3 on immune regulation during HIV-1 infection was investigated through assessment of CTL response with frequencies of Tim-3 expression and blocking effect.

\section{Results}

Tim-3 was found to be highly expressed on HIV-specific CD4+ T cells and CD8+ T cells, especially in primary infectors and AIDS patients. The frequencies of Tim-3 expression correlate with disease progression. The level of Tim-3 expression was related with cytokines production and blockade of Gal-9/TIM-3 signaling partially restored the ability of HIV-specific T cells to secrete cytokines in vitro.

\section{Conclusion}

The frequencies of Tim-3 expression correlate with disease progression in HIV-1 infected individuals and manipulating Gal-9/TIM-3 signaling pathway may

$\overline{\text { National Center for AIDS Control and Prevention, China CDC, Beijing, China }}$ provide a novel therapeutic measure to control HIV-1 replication.

Published: 13 September 2012

doi:10.1186/1742-4690-9-S2-P270

Cite this article as: Liu et al:: Highly expression of Tim-3 on HIV-specific $T$ cells associated with disease progression and T-cell exhaustion in HIV1 infected Chinese. Retrovirology 2012 9(Suppl 2):P270.
Submit your next manuscript to BioMed Central and take full advantage of:

- Convenient online submission

- Thorough peer review

- No space constraints or color figure charges

- Immediate publication on acceptance

- Inclusion in PubMed, CAS, Scopus and Google Scholar

- Research which is freely available for redistribution
() Bïomed Central (c) 2012 Liu et al; licensee BioMed Central Ltd. This is an Open Access article distributed under the terms of the Creative Commons Attribution License (http://creativecommons.org/licenses/by/2.0), which permits unrestricted use, distribution, and reproduction in any medium, provided the original work is properly cited. 